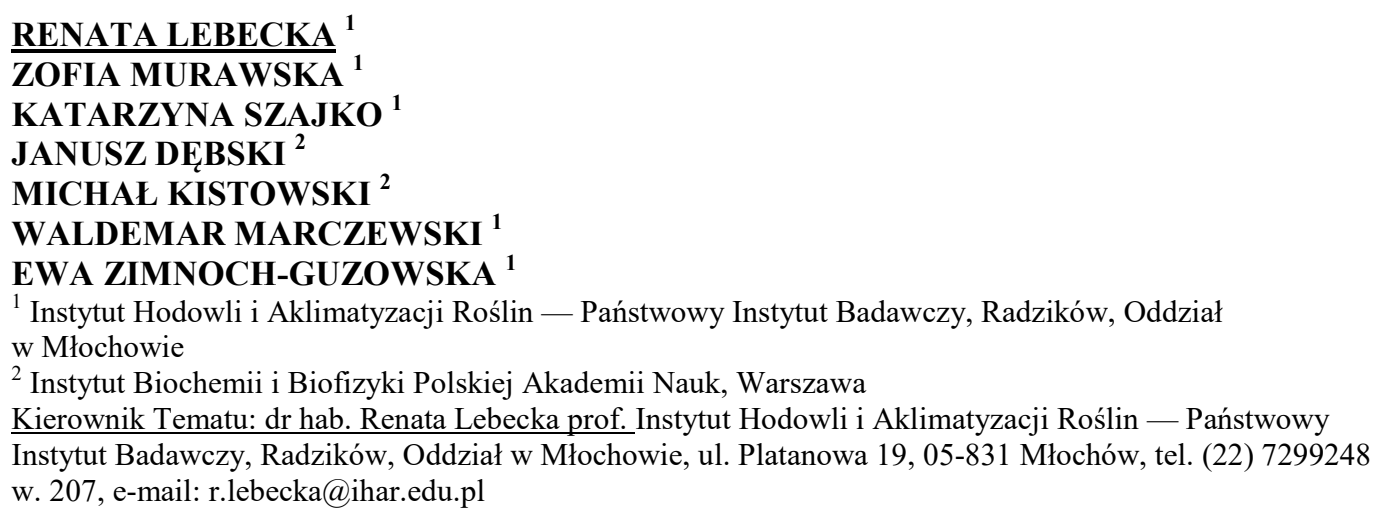

Prace zostaty wykonane $w$ ramach badań podstawowych na rzecz postępu biologicznego $w$ produkcji roślinnej na podstawie decyzji Ministra Rolnictwa $i$ Rozwoju Wsi nr HOR.hn.802.19.2018, Zadanie 56.

\title{
Badania ekspresji i genetyczna charakterystyka odporności na bakterie Dickeya solani w wyróżnionych źródłach odporności w ziemniaku na poziomie diploidalnym
}

\section{Research on the expression and genetic characterization of the resistance to bacteria Dickeya solani in selected for resistance diploid potato}

\author{
Słowa kluczowe: białka ziemniaka, Dickeya solani, loci cech ilościowych, mokra zgnilizna bulw \\ ziemniaka, odporność
}

\section{CEL PODJETTEGO TEMATU I PROWADZONYCH BADAŃ}

Mokra zgnilizna bulw ziemniaka to choroba powodowana przez kilka gatunków bakterii pektynolitycznych należących do dwóch rodzajów: Pectobacterium i Dickeya. Bakterie Dickeya spp. są bardziej agresywne od innych bakterii pektynolitycznych (Czajkowski i in., 2013). Straty ekonomiczne powodowane przez bakterie pektynolityczne to: obniżenie wielkości plonu bulw, utrata części plonu w czasie przechowywania, wystąpienie czarnej nóżki w czasie sezonu wegetacyjnego, koszty związane $\mathrm{z}$ degradacją plantacji nasiennych. Nie stosuje się ochrony chemicznej 
do zwalczania bakterii wywołujących choroby ziemniaka. Odporność bulw ziemniaka na bakterie pektynolityczne jest cechą poligeniczną (Zimnoch-Guzowska i in., 2000).

\section{Celem tematu jest:}

- (1) zmapowanie odporności na bakterie D. solani w diploidalnej nieselekcjonowanej populacji ziemniaka, otrzymanej po skrzyżowaniu formy wysoko odpornej z formą o niskiej odporności na te bakterie oraz

- (2) znalezienie różnic $\mathrm{w}$ profilach białkowych odmian ziemniaka, różniących się między sobą poziomem odporności bulw na zakażenie bakteriami D. solani, 8 lub 48 godzin po inokulacji.

\section{CEL (1). OPIS WYNIKÓW}

Przeprowadzono analizę markerów DArTseq 186 osobników potomnych i ich form rodzicielskich, wykonano ocenę fenotypową odporności bulw na bakterie D. solani (Lebecka, 2017) oraz oceniono zawartość skrobi w bulwach ziemniaka w populacji mapującej (Zgórska, 2001). Testowana cecha przyjmowała rozkład normalny. Średnia masa zgniłej tkanki genotypów potomstwa populacji mapującej wynosiła 2,3 g, zakres cechy od 0,0 do 7,6 g, u odpornej formy rodzicielskiej DG 00-270 wynosiła 0,8 g, a u podatnej formy, DG 08-305 - 5,9 g. Zawartość skrobi w formach rodzicielskich populacji mapującej wynosiła 20,5\% w DG 00-270 i 17,3\% w DG 08-305. Zakres badanej cechy w potomstwie wynosił od $11,4 \%$ do $23,9 \%$, ze średnią populacji $17,7 \%$.

\section{CEL (1). WNIOSKI Z PROWADZONYCH BADAŃ}

Testowanie porażenia bulw w teście sztucznej inokulacji będzie powtórzone w trzecim (ostatnim) roku badań. Dane będą wykorzystane do mapowania loci cech ilościowych (QTLs) odporności bulw na bakterie $D$. solani. Ocena zawartości skrobi w kolejnym roku badań umożliwi zbadanie związku zawartości skrobi z odpornością bulw na mokrą zgniliznę. Badania będą kontynuowane.

\section{CEL (2). OPIS WYNIKÓW}

$\mathrm{Na}$ podstawie trzyletniej oceny porażenia bulw w testach laboratoryjnych przeprowadzonych $\mathrm{w}$ poprzednich latach tego projektu (Lebecka, 2017) do badań proteomicznych wybrano dwie odmiany o wysokiej odporności (Bea i Humalda) i trzy odmiany o niższej odporności (Katahdin, Ulster Supreme i Irys). Próbki z pięciu odmian ziemniaka pobierano z bulw zranionych inokulowanych bakteriami $D$. solani, z bulw zranionych traktowanych wodą ( 8 i $48 \mathrm{~h}$ po inokulacji) oraz z bulw nieranionych $(8 \mathrm{~h}$ po inokulacji). Doświadczenia prowadzono w dwóch terminach. Pobierano od dwóch do czterech fragmentów z każdej kombinacji doświadczenia. Białka izolowano według protokołu opracowanego w poprzednich latach tego projektu (Murawska i in., 2017). Analizę próbek wykonano metodą wysokosprawnej chromatografii cieczowej sprzężonej $\mathrm{z}$ tandemowym spektrometrem mas (LC-MS/MS). Programem Diffprot (Malinowska i in., 2012) porównano listy peptydów danych grup eksperymentalnych pomiędzy sobą, 
obliczając zależności statystyczne i typując białka, których poziom ekspresji pomiędzy badanymi grupami różnił się $\mathrm{W}$ sposób istotny $(\mathrm{P} \leq 0,1)$, co najmniej 1,5 razy. (1) Porównano białka $\mathrm{z}$ bulw inokulowanych bakteriami $D$. solani $\mathrm{z}$ białkami bulw zranionych i traktowanych wodą. Przeprowadzono cztery porównania, dla grupy odmian odpornych i podatnych, po 8 i 48 h po inokulacji. Wyróżniono wyłącznie jedno białko różnicowe, peroksydazę, w grupie odmian odpornych, 48 godzin po inokulacji. (2) Porównano białka z bulw odmian odpornych z podatnymi. We wczesnej fazie infekcji, 8 godzin po inokulacji, wyróżniono 4 białka (patatyny, inhibitory proteinaz $\mathrm{w}$ tym inhibitor chymotrypsyny), których ekspresja była istotnie wyższa w odmianach odpornych, w próbkach pobranych zarówno $\mathrm{z}$ bulw inokulowanych bakterią jak i traktowanych wodą, natomiast $\mathrm{w}$ bulwach nieranionych istotnie większą ekspresję stwierdzono dla białka patatyny. Wyższą ekspresją w odmianach odpornych, tylko po inokulacji, charakteryzowały się dwa białka, inhibitor proteinazy PTI i syntetaza tiaminotiazolowa. W późniejszej fazie infekcji w odmianach odpornych w obu rodzajach bulw, inokulowanych i traktowanych wodą, było istotnie więcej inhibitorów proteinaz, patatyny (tak samo jak po $8 \mathrm{~h}$ ) i inhibitorów proteazy serynowej. Wyróżniono białka o wyższej ekspresji w odmianach odpornych wyłącznie po inokulacji bakteriami, inhibitory proteazy aspartylowej, oksydazy polifenolowe i endoplazminy.

Wykonano dwie analizy głównych składowych dla wszystkich prób z doświadczenia (1) po $8 \mathrm{~h}$ oraz (2) po 8 i $48 \mathrm{~h}$. Analiza próbek z doświadczenia po 8 h wyjaśnia $19 \%$ zmienności a analiza po $48 \mathrm{~h}-26 \%$ zmienności, mimo to analiza po $8 \mathrm{~h}$ pozwala na oddzielenie odmian odpornych od podatnych na podstawie drugiej składowej (PC2). Po $48 \mathrm{~h}$ różnice pomiędzy jedną $\mathrm{z}$ odpornych odmian, a pozostałymi odmianami podatnymi zaczynają się zacierać.

\section{CEL (2). WNIOSKI Z PROWADZONYCH BADAŃ}

Wykazano różnice w białkach pomiędzy odpornymi i podatnymi odmianami na mokrą zgniliznę bulw, w początkowej i późniejszej fazie infekcji. Większość białek różnicowych występuje w bulwach inokulowanych bakteriami $\mathrm{w}$ zranienia $\mathrm{i}$ w bulwach zranionych traktowanych wodą. W bulwach nieranionych $8 \mathrm{~h}$ po inokulacji, spośród białek różnicowych wykrytych w początkowej i późniejszej fazie infekcji, tylko patatyny występowały $\mathrm{w}$ większej ilości $\mathrm{w}$ odmianach odpornych $\mathrm{w}$ porównaniu $\mathrm{z}$ podatnymi. Na podstawie analizy głównych składowych 8 h oraz 8 i 48 h po inokulacji zakładamy, że różnice obserwowane w czasie wczesnej fazy infekcji, 8 h po inokulacji, mogą odgrywać większą rolę w hamowaniu rozwoju objawów choroby.

\section{LITERATURA}

Czajkowski R., De Boer W. J., Van der Zouwen P.S., Kastelein P., Jafra S., de Haan E.G., Van den Bovenkamp G. W., Van der Wolf J. M. 2013. Virulence of 'Dickeya solani' and Dickeya dianthicola biovar-1 and -7 strains on potato (Solanum tuberosum). Plant Pathol. 62: 597 - 610.

Lebecka R. 2017. Screening for potato resistance to blackleg and soft rot. Plant Breed Seed Sci 75: 97 - 104 DOI:10.1515/plass-2017-00013. 
Malinowska A., Kistowski M., Bakun M., Rubel T., Tkaczyk M., Mierzejewska J., Dadlez M. 2012. Diffprot - software for non-parametric statistical analysis of differential proteomics data. J. Proteomics 75 (13): $4062-4073$.

Murawska Z. Dębski J., Szajko K., Lebecka R. 2017. Isolation of proteins from potato tubers. Plant Breed Seed Sci 75: 23 - 27 DOI: 10.1515/plass-2017-0005.

Zgórska K. 2001. Oznaczanie zawartości skrobi w bulwach ziemniaka. W: Monografie i Rozprawy Naukowe IHAR Radzików, 10a: $113-116$.

Zimnoch-Guzowska E., Marczewski W., Lebecka R., Flis B, Schäfer-Pregl R., Salamini F., Gebhardt C. 2000. QTL analysis of new sources of resistance to Erwinia carotovora ssp. atroseptica in potato done by AFLP, RLFP, and resistance-gene-like markers. Crop Sci. 40: 1156 - 1167. 